\title{
Viral and bacterial infection among hospitalized-suspected influenza A/H5N1 patients in Indonesia, 2008-2009
}

\author{
Agustiningsih, Reni Herman, Ririn Ramadhany, Eka Pratiwi, Kartika D. Puspa, Vivi Setiawaty \\ Center of Biomedical and Basic Technology of Health, National Institute of Health Research and Development, Jakarta, Indonesia
}

\begin{abstract}
Abstrak
Latar belakang: Adanya kasus-kasus tersangka H5N1 dengan manifestasi klinis berat namun negatif virus H5N1 menyebabkan perlunya investigasi adanya etiologi lain pada pasien-pasien tersebut. Tujuan penelitian ini adalah untuk mengetahui patogen saluran pernafasan lain pada pasien tersangka H5N1 sehingga diperoleh data mikroorganisme penyebab ISPA berat.
\end{abstract}

\begin{abstract}
Metode: Penelitian ini menggunakan bahan biologi tersimpan (BBT) berupa sampel klinis (apus hidung atau tenggorok, tracheal aspirate dan bronchoalveolar lavage) dari pasien tersangka H5N1 yang telah terkonfirmasi negatif virus H5N1. Dilakukan pemeriksaan terhadap 16 virus dan 8 bakteri menggunakan Multiplex PCR serta Real Time PCR pada BBT dari 230 kasus tersangka H5N1 yang dirawat. BBT tersebut diterima Badan Penelitian dan Pengembangan Kesehatan pada Juli 2008 hingga Juni 2009.

Hasil: Dari 230 kasus tersangka H5N1, Klebsiella pneumoniae merupakan bakteri yang paling dominan ditemukan pada anak-anak dan dewasa. Virus influenza A (non H5N1) merupakan virus penyebab yang umum ditemukan pada anak-anak sedangkan pada orang dewasa gambaran etiologi oleh virus cukup bervariasi dengan ditemukannya virus influenza A (non H5), Enterovirus, HRV A/B, Coronavirus 229E/NL63 dengan presentase yang rendah. Infeksi campuran oleh bakteri Klebsiella pneumoniae, Streptococcus pneumoniae and Haemophillus influenzae umumnya ditemukan pada anak-anak sedangkan Klebsiella pneumoniae dan Streptococcus pneumoniae merupakan infeksi campuran yang dominan pada dewasa. Virus influenza A and Klebsiella pneumoniae merupakan penyebab utama infeksi campuran oleh bakteri dan virus yang ditemukan pada anak-anak.
\end{abstract}

Kesimpulan: Berdasarkan pemeriksaan yang dilakukan, bakteri merupakan penyebab ISPA terbanyak pada anak-anak maupun dewasa, walaupun juga ditemukan infeksi yang disebabkan oleh virus-virus yang umum menyerang saluran pernafasan. Infeksi campuran oleh bakteri dan virus juga ditemukan baik pada anak-anak maupun dewasa. (Med J Indones. 2012;21:77-82)

\begin{abstract}
Background: Since a lot of suspected H5N1 cases with severe ARI manifestation were hospitalized and negative for H5N1, it raised a concern to investigate the other etiologies among hospitalized-suspected H5N1 cases. The aim of present study is to investigate the other respiratory pathogens of hospitalized-suspected H5N1 cases in which will provide valuable insight in the etiologies and epidemiology data of ARI.

Methods: We tested the archived respiratory clinical specimens (nasal or throat swab, tracheal aspirate and bronchoalveolar lavage) that were already confirmed as negative H5N1 for 16 viruses and 8 bacteria existence by Multiplex PCR and RealTime PCR from 230 hospitalized-suspected H5N1 cases received in July 2008 to June 2009.

Results: Of the 230 hospitalized-suspected H5N1 cases, Klebsiella pneumoniae was the most dominant bacterial pathogen in children and adult. Moreover, the common viral pathogens in children was influenza A (non H5), while it was varied in adults as influenza A (non H5), Enterovirus, HRV A/B, Coronavirus 229E/NL63 were found very low. Bacterial mix infection of Klebsiella pneumoniae, Streptococcus pneumoniae and Haemophillus influenzae mainly occurred in children while co-infections of Klebsiella pneumoniae and Streptococcus pneumoniae were frequently found in adults. In addition, the major bacterial-viral mix infection found among children was influenza A and Klebsiella pneumoniae.

Conclusion: From all of the samples tested, bacterial infections remain the most common etiologies of ARI in adults and children although there were infections caused by viruses. Mix infection of bacterial and viral also found among adults and children. (Med J Indones. 2012;21:77-82)
\end{abstract}

Keywords: Acute respiratory infection, $H 5 N 1, P C R$

Acute Respiratory Infections (ARI) is the prominent cause of morbidity and hospitalization throughout the world, especially in people at high risk such as infants, children and elderly. It also the leading cause of death in children in developing country. ${ }^{1-3}$ However, ARI was not considered to be a major public health concern particularly in developing countries. The 1997 influenza $\mathrm{A} / \mathrm{H} 5 \mathrm{~N} 1$ outbreak in human ${ }^{4}$ and Severe Acute Respiratory Syndrome (SARS) epidemic by coronavirus in 2003 in Hong Kong emphasize the risk posed by ARI in humans. ${ }^{5}$

The causative agents of ARI cover a wide variety of microorganisms. Viruses such as respiratory syncytial virus (RSV), rhinoviruses, adenoviruses, parainfluenza virus type $1,2,3$, influenza virus type $\mathrm{A}$ and $\mathrm{B}$, and enterovirus are identified to be the common cause of acute respiratory infection. ${ }^{3,6,7}$ In addition, some 
new causes of acute respiratory infection have been identified in the recent years. Human metapneumovirus, human bocavirus and several coronaviruses have been discovered. ${ }^{1,8,9}$ Moreover, bacterial agents are also recognized as the cause of acute respiratory infection. Streptococcus pneumoniae, Haemophilus influenzae, Enteric Gram negative (Escherichia coli, Klebsiella pneumoniae, Pseudomonas aeruginosa) Mycoplasma, Chlamidophilla, and Legionella are commonly reported to be the cause of ARI., ${ }^{9,10}$

Following the H5N1 outbreak in poultry and human, influenza associated with the severe acute respiratory infection was given higher attention in Indonesia. Until March 2011, 176 confirmed cases of H5N1 were reported and 145 had been fatal, putting Indonesia as the country with the highest number of H5N1 human cases in the world. ${ }^{11}$ Since H5N1 virus become endemic in poultry while H5N1 human cases with severe illness and death continue to accumulate, H5N1 virus is consider as major public health problem due to severe illness manifestation and death. ${ }^{12}$ In contrast, a large number of suspected cases of $\mathrm{H} 5 \mathrm{~N} 1$ with severe acute respiratory illness were negative for influenza viruses. Based on Severe Acute Respiratory Illness (SARI) Surveillance data from April 2008 until March 2009, it was known that only $6 \%$ of the patients with severe acute respiratory symptoms were caused by influenza virus, while the other pathogens remain unknown. ${ }^{13}$

The most comprehensive data on the etiologies of ARI originate from develop countries. ${ }^{14}$ Currently, limited data are available concerning the epidemiology of the other etiologies of ARI in Indonesia as most known data relate mainly to influenza infection. ${ }^{13,15}$ Ever since both $\mathrm{H} 5 \mathrm{~N} 1$ and SARS originated in Asia, such epidemiology data on etiologic of ARI are beneficial to identify any emerging causes of ARI that potential to become serious public health problem in Indonesia. Furthermore, the availability of other etiologies of ARI can provide valuable information for development of guidance of disease management and for further appropriate health intervention such as diagnostic assay and drugs development.

Previous studies have shown that molecular biology techniques based on PCR have been developed in recent years and these methods were far more sensitive and useful for the detection of pathogens causing ARIs. ${ }^{6,10}$ In this study, multiplex PCR and real-time PCR were used to identify the other etiologies of ARI among suspected H5N1 cases that admitted to hospital in Indonesia from July 2008 to June 2009.

\section{METHODS}

\section{Ethical approval}

The present study had been approved by the Health Research Ethic Committee, National Institute Research and Development, Ministry of Health.

\section{Study population}

The study used archival clinical samples obtained from hospitalized-suspected influenza A(H5N1) patients that routinely sent to National Institute of Health Research and Development (NIHRD) as National Influenza Centre from July 2008 to June 2009. Samples with complete demographic data such as sex, age, date of sample collection, date of onset and clinical diagnosis obtained from patient's Case Report Form (CRF) were used while samples with insufficient volume and incomplete data were excluded. All of samples were confirmed negative H5N1 with real-time RT-PCR and conventional RT-PCR and also stored in deep freeze $-80^{\circ} \mathrm{C}$. Around 245 archival clinical samples (nose swab, nasopharyngeal aspirate, tracheal aspirate, bronchoalveolar lavage) of 230 hospitalized-suspected $\mathrm{H} 5 \mathrm{~N} 1$ cases that were admitted to hospital with severe respiratory symptoms such as fever $\geq 38^{\circ} \mathrm{C}$ and cough, and also difficulty breathing symptoms, dyspneu, chest indrawing and stridor when rest or chest X-ray that shows acute lung infiltrate were enrolled.

\section{DNA and RNA isolation}

Bacterial and Viral DNA were extracted directly from $200 \mu \mathrm{L}$ of each samples using QIAamp DNA Mini Kit (Qiagen, Hilden, Germany) while QIAamp Viral RNA Mini Kit (Qiagen, Hilden, Germany) was used to obtain the viral RNA from $140 \mu \mathrm{L}$ samples. The nucleic acid was isolated according to manufacturer's instruction. Molecular grade water was used as negative control at the same time with samples in every batch of nucleic acid isolation.

\section{Reverse transcriptase of viral RNA}

Reverse transcriptase to synthesize complementary DNA from Viral RNA was performed in Thermal Cycler using Superscript III First Strand Synthesis System (Invitrogen, Carlsbad, CA). Complementary DNA was synthesized using Random Hexamer and RNA sample as a template according to manufacturer's instruction.

\section{Multiplex PCR and real-time PCR}

Other etiologies of ARI were tested for 16 viruses and 8 bacterial by multiplex PCR and real-time PCR. 
Two multiplex PCR methods, developed by Seegene, Korea, were use to detect 12 major respiratory viruses (Seeplex $^{\circledR}$ RV12 ACE Detection) and 6 bacterial pathogens (Seeplex ${ }^{\circledR}$ PneumoBacter ACE detection) (10). Seeplex ${ }^{\circledR}$ RV12 ACE Detection detects human adenovirus (AdV), influenza A virus (FluA), influenza $B$ virus (FluB), human respiratory syncytial virus A (RSVA), human respiratory syncytial virus B (RSVB), human metapneumovirus (MPV), human parainfluenzavirus 1 (PIV1), human parainfluenzavirus 2 (PIV2), human parainfluenzavirus 3 (PIV3), human rhinovirus A/B (HRV), human coronavirus 229E/ NL63 (229E/NL63) and human coronavirus OC43/ HKU1 (OC43/HKU1). Seeplex ${ }^{\circledR}$ PneumoBacter ACE detection was used to identify 6 bacterial pathogens such as Mycoplasma pneumonia, Haemophilus influenzae, Streptococcus pneumoniae, Chlamydophila pneumonia, Legionella pneumophila and Bordetella pertussis. Multiplex PCR methods were performed according to manufacturer's instruction. The multiplex PCR products were visualized under UV light after electrophoresis through an ethidium bromide-stained $2 \%$ agarose.

Furthermore, specific real-time PCRs methods developed by Oxford University Clinical Research Unit, Vietnam (unpublished), were used for detection of other viruses and bacteria, such as Enterovirus, Parainfluenza 4, Bocavirus including additional rhinoviruses and parechoviruses, Chlamydophila psitacci, Klebsiella pneumoniae. Five microliter of nucleic acid was used for real-time PCR in a total volume of $25 \mu \mathrm{L}$. The reaction mix composition was $1 \mathrm{x}$ PCR buffer, $4 \mathrm{mM} \mathrm{MgCl}_{2}$ solution, $100 \mu \mathrm{M}$ of each deoxynucleoside triphosphates, $0.4 \mu \mathrm{M}$ of each probe, forward and reverse primer, and 1 $\mathrm{U} / \mu \mathrm{L}$ of HotStart Taq DNA polymerase (Qiagen). Realtime PCR for Klebsiella pneumoniae was performed as follows: $94^{\circ} \mathrm{C}$ denaturation for 15 minutes followed by 45 cycles of denaturation at $95^{\circ} \mathrm{C}$ for 1 second, annealing, elongation and data collection at $60^{\circ} \mathrm{C}$ for 30 seconds, and ended by holding the temperature at $4^{\circ} \mathrm{C}$. Additionally, real-time PCR condition for Chlamydia, Bocavirus, Enterovirus, Rhinovirus, Parechovirus, Parainfluenzavirus 4 was described as follows: $94^{\circ} \mathrm{C}$ for 15 minutes of denaturation followed by 45 cycles of denaturation at $95^{\circ} \mathrm{C}$ for 15 seconds, annealing, elongation and data collection at $60^{\circ} \mathrm{C}$ for 1 minute. Water was used as negative control, while plasmid with PCR product insert at a concentration of 1000 copies/ reaction was used as positive control (provided from OUCRU, Vietnam) to validate the test.

\section{RESULTS}

A total of 245 archive respiratory specimens of 230 hospitalized-suspected $\mathrm{H} 5 \mathrm{~N} 1$ cases were received by NIHRD from July 2008 until June 2009. Table 1 describes the demographic of the samples enrolled in the study. Based on sex, the distribution among 230 cases was $50.9 \%$ female and $49.1 \%$ of male, while the distribution of patient based on age could be divided into two main age groups; $>15$ years old or adult and $<$ 15 years old or children.

Table 1. Demographic features of hospitalized-suspected H5N1 patient with ARI $(n=230)$

\begin{tabular}{|c|c|c|c|}
\hline \multirow{2}{*}{ Age groups } & \multicolumn{2}{|c|}{ Sex } & \multirow{2}{*}{$\begin{array}{c}\text { Total } \\
\mathrm{n}(\%)\end{array}$} \\
\hline & Female & Male & \\
\hline \multicolumn{4}{|l|}{ Children } \\
\hline$<1$ years old & 12 & 5 & $17(7.4)$ \\
\hline $1-5$ years old & 18 & 27 & 45 (19.6) \\
\hline $6-14$ years old & 20 & 26 & $46(20.0)$ \\
\hline Subtotal & 50 & 58 & $108(47.0)$ \\
\hline \multicolumn{4}{|l|}{ Adult } \\
\hline 15-59 years old & 65 & 48 & $113(49.1)$ \\
\hline$\geq 60$ years old & 2 & 7 & $9(3.9)$ \\
\hline Subtotal & 67 & 55 & $122(53.0)$ \\
\hline Total & $117(50.9)$ & $113(49.1)$ & $230(100)$ \\
\hline
\end{tabular}

The etiologies of ARI in children were shown in table 2 . Single infections by viral pathogens in children were commonly caused by influenza A $(2.8 \%)$, followed by human rhinovirus A/B (HRV A/B) $(1.9 \%)$, human coronavirus 229E/NL $63(1.9 \%)$ and Adenovirus (1.9\%). The incidence of Enterovirus, Bocavirus, PIV 1, PIV 2 and PIV 3 were low, accounted for $0.9 \%$ each pathogen. Moreover, Klebsiella pneumoniae was the most dominant bacterial pathogen, followed by Streptococcus pneumoniae and Haemophillus influenzae, resulted $14 \%, 8.4 \%$ and $0.9 \%$, respectively.

Table 2. ARI etiologies in children $(n=108)$

\begin{tabular}{lc}
\hline \multicolumn{1}{c}{ Pathogen } & $\mathrm{n}(\%)$ \\
\hline Virus & $3(2.8)$ \\
Influenza A & $1(0.8)$ \\
Enterovirus & $2(1.9)$ \\
HRV A/B & $2(1.9)$ \\
Coronavirus 229E/NL 63 & $2(1.9)$ \\
ADV & $1(0.9)$ \\
Bocavirus & $1(0.9)$ \\
PIV 1 & $1(0.9)$ \\
PIV 2 & $1(0.9)$ \\
PIV 3 & \\
Bacteria & $9(8.4)$ \\
S. pneumoniae & $15(14)$ \\
K. pneumoniae & $1(0.9)$ \\
H. influenzae & $37(34.6)$ \\
Mix infection* & $32(29.9)$ \\
Negative & $108(100)$ \\
Total
\end{tabular}

*Described in different table 
Thirty-two samples among children were negative $(29.9 \%)$ and 37 samples $(34.6 \%)$ were identified to have double infection. Mix bacterial infections among 37 samples in children were commonly caused by Streptococcus pneumoniae and Haemophillus influenzae as well as infection by Streptococcus pneumoniae, Klebsiella pneumoniae and Haemophillus influenzae (16.22\%). In addition, the major bacterialviral infections among children were influenza A and Klebsiella pneumoniae, resulted $10.81 \%$ cases.

Table 3. Bacterial and bacterial-viral mix infection in children $(n=37)$

\begin{tabular}{lc}
\hline \multicolumn{1}{c}{ Pathogen } & $\mathrm{n}(\%)$ \\
\hline Bacteria-bacteria & $16(43.2)$ \\
Virus-bacteria & $21(56.8)$ \\
Total & $37(100)$ \\
\hline
\end{tabular}

Table 4 shows the etiologies of ARI in adults. Influenza A, Enterovirus, human rhinovirus A/B (HRV A/B), Coronavirus 229E/NL 63 and Metapneumovirus were identified causing single infection with similar percentage $(0.8 \%$ for every pathogens). On the other hand, most prevalent bacterial infection was Klebsiella pneumoniae (22.5\%), followed by Streptococcus pneumoniae and Haemophillus influenzae with $12.5 \%$ and $2.5 \%$ cases, respectively. Among 122 adult samples, $41.7 \%$ were negative while $18.3 \%$ samples were identified with mix infection. The number of bacterial mix infection within 122 adults samples were lower than mix infection in children, showed distinctively in table 5 . In addition, frequent double bacterial infection by Streptococcus pneumoniae and Klebsiella pneumoniae was detected in $27.27 \%$ samples.

Table 4. ARI etiologies in adults $(n=122)$

\begin{tabular}{lc}
\hline Pathogen & $\mathrm{n}(\%)$ \\
\hline Virus & $1(0.8)$ \\
Influenza A & $1(0.8)$ \\
Enterovirus & $1(0.8)$ \\
HRV A/B & $1(0.8)$ \\
Coronavirus 229E/NL 63 & $1(0.8)$ \\
MPV & \\
Bacteria & $15(12.5)$ \\
S. pneumoniae & $27(22.5)$ \\
K. pneumoniae & $3(2.5)$ \\
H. influenza & $22(18.3)$ \\
Mix infection* & $50(41.7)$ \\
Negative & $122(100)$ \\
Total & \\
\hline
\end{tabular}

*Described in different table
Table 5. Bacterial and bacterial-viral mix infection in adult ( $\mathrm{n}$ =22)

\begin{tabular}{lc}
\hline Pathogen & $\mathrm{n}(\%)$ \\
\hline Bacteria-virus & $12(54.5)$ \\
Bacteria-bacteria & $10(45.5)$ \\
Total & $22(100)$ \\
\hline
\end{tabular}

\section{DISCUSSION}

The H5N1 infection continues to constitute a major health problem in Indonesia since it first occurrences in $2005 .{ }^{11}$ As the human cases continue to accumulate, the awareness of the emergence of other etiologies of ARI is even greater. The identification of other etiologies beside H5N1 among hospitalized-suspected$\mathrm{H} 5 \mathrm{~N} 1$ patient in Indonesia becomes crucial in order to identify the other etiologies of ARI since only limited data related ARI etiologies are available. Therefore data from this study would provide essentials information.

In this study, $50.9 \%$ of hospitalized-suspected $\mathrm{H} 5 \mathrm{~N} 1$ patient with ARI were female while $49.1 \%$ were male, showing the female and male ratio was slightly similar. This ratio is parallel with other study reported in developing country. ${ }^{7}$ In the other hand the distribution based on age was not alike. Previous studies ${ }^{3,7,16}$ reported that the most frequent cases with pneumonia were children less than 5 years old while in the present study, $53 \%$ of the total cases were adult. The explanation to this is the enrolled patients in the present study were patient that was suspected for $\mathrm{H} 5 \mathrm{~N} 1$ infection and shows rapid progress of severe acute respiratory illness. Therefore all suspected-hospitalized cases were varied in age with the prominent patients is adult as the $\mathrm{H} 5 \mathrm{~N} 1$ confirmed cases in Indonesia are commonly adult. ${ }^{17,18}$

Influenza A (non H5N1) was found to be the most common viral pathogen caused single infection among hospitalized-suspected H5N1 patients. Further subtype examination confirms that these viruses were H3 viruses (data not shown). It is well known that influenza A infections have wide range of symptoms, varied from mild or asymptomatic respiratory illness to severe pneumonia even death. The H5 infection typically manifests as severe pneumonia that often progresses rapidly into acute respiratory distress syndrome within short period of time, ${ }^{17}$ while the clinical features of $\mathrm{H} 3 \mathrm{~N} 2$ and $\mathrm{H} 1 \mathrm{~N} 1$ infection usually mild or asymptomatic respiratory illness. ${ }^{1}$ Nevertheless, previous study shows that H3N2 infection was associated with lower respiratory illness and hospitalization ${ }^{19,20}$ suggested that H3N2 virus could also cause severe ARI even though viral subtype are not the only factor that related to the severity of illness.

Other viral pathogens that found in this study are Enterovirus, Human Rhinovirus, Human Coronavirus, 
Adenovirus, Parainfluenza and Human Metapneumovirus which also have been reported in other studies to cause ARI, both in children and adult. ${ }^{6,7,9,21}$ Although Rhinovirus is associated with common cold as this virus is normally commensals in upper respiratory tract, Rhinovirus are also one of viral pathogen that cause severe lower ARI ${ }^{3,7}$ In addition, bacterial infections found in this study were commonly Klebsiella pneumoniae, Strptococcus pneumoniae and Haemophillus influenzae. This finding was similar with previous study where Streptococcus pneumoniae is the prominent pathogen causing community acquired pneumonia in Asian countries while Klebsiella pneumoniae and Haemophillus influenzae were the commonest bacterial pathogens in South East Asia. 9,22,23

Co-infection of viral and bacterial pathogen cases were found within the present study although only minor cases. Co-infections between one of viral pathogen such as; influenza A, Coronavirus 229E/NL 63, Rhinovirus, Bocavirus, Adenovirus, Parainfluenza Virus, respiratory syncytial virus and bacterial, Klebsiella pneumoniae, Streptococcus pneumoniae and Haemophillus influenzae were detected. This finding correlates with previous studies that illustrate the common viral-bacterial agents that cause ARI. ${ }^{7,21,24}$ Co-infection of influenza A virus and bacterial such as Streptococcus pneumoniae is commonly recognized since secondary infection by Streptococcus pneumoniae were thought to be the cause of death during the 1918 Spanish Flu pandemic. Additionally, secondary bacterial pneumonia and acerbation of underlying conditions during epidemic years are also associate to hospitalization and deaths. ${ }^{25}$ Viral infection within the respiratory tract may induce epithelial damage as well as change pulmonary function and in turn exaggerate bacterial superinfection..$^{25,26}$

Although this study describes the etiologies of ARI in hospitalized-suspected $\mathrm{H} 5 \mathrm{~N} 1$ patient, we did not investigate the specific clinical symptoms among the patients due to data limitation. Specific clinical symptoms may accomplish the finding of the viral and bacterial agents among the enrolled patients in association with the severity of the illness.

This study utilizes sensitive and reliable molecular biology methods such as PCR which is useful for the detection of agents that could not be tested with culture or ELISA. In addition, PCR assay for viral and bacterial identification is also suitable technique that could be applied as detection assay in the field due to its feasibility, specificity and sensitivity.

In summary, this report describes the other etiologies of ARI among hospitalized-suspected H5N1 in Indonesia. Other viruses and bacteria were found in the suspectedH5N1 patients that were admitted to hospital with clinical symptoms of ARI.

\section{Acknowledgments}

This study is a part of collaborative work with the South East Asia Infectious Disease Clinical Research Network (SEAICRN) supported by the US National Institute for Allergy and Infectious Diseases (NIAID) of the US National Institutes of Health and the Wellcome Trust UK. We acknowledge Professor Agus Purwadianto and Drs. Ondri Dwi Sampurno from NIHRD for their suggestion concerning the role of NIHRD in the present collaborative study. We also address our appreciation to our colleagues from the Virology Laboratory, NIHRD for their contributions performing the PCR test in this project.

\section{REFERENCES}

1. Mackie PL. The classification of viruses infecting the respiratory tract. Paediatr Respir Rev. 2003;4:84-90.

2. Williams BG, Gouws E, Boschi-Pinto C, Bryce J, Dye C. Estimates of world-wide distribution of child deaths from acute respiratory infections. Lancet Infect Dis. 2002;2:25-32.

3. Niang MN, Diop OM, Sarr FD, Goudiaby D, Malou-Sompy $\mathrm{H}$, Ndiaye K, et al. Viral etiology of respiratory infections in children under 5 years old living in tropical rural areas of Senegal: The EVIRA project. J Med Virol. 2010;82:866-72.

4. Chan PK. Outbreak of avian influenza A(H5N1) virus infection in Hong Kong in 1997. Clin Infect Dis. 2002;34 Suppl 2:S58-64.

5. Peiris JS, Lai ST, Poon LL, Guan Y, Yam LY, Lim W, et al. Coronavirus as a possible cause of severe acute respiratory syndrome. Lancet. 2003;361:1319-25.

6. Suwanjutha S, Sunakorn P, Chantarojanasiri T, Siritantikorn S, Nawanoparatkul S, Rattanadilok Na Bhuket $\mathrm{T}$, et al. Respiratory syncytial virus-associated lower respiratory tract infection in under-5-year-old children in a rural community of central Thailand, a population-based study. J Med Assoc Thai. 2002;85 Suppl 4:S1111-9.

7. Khadadah M, Essa S, Higazi Z, Behbehani N, Al-Nakib W. Respiratory syncytial virus and human rhinoviruses are the major causes of severe lower respiratory tract infections in Kuwait. J Med Virol. 2010;82:1462-7.

8. I PM, Nelson EA, Cheuk ES, Leung E, Sung R, Chan PK. Pediatric hospitalization of acute respiratory tract infections with Human Bocavirus in Hong Kong. J Clin Virol. 2008;42:72-4.

9. Tsang KW, File TM Jr. Respiratory infections unique to Asia. Respirology. 2008;13:937-49.

10. Drews SJ, Blair J, Lombos E, DeLima C, Burton L, Mazzulli $\mathrm{T}$, et al. Use of the Seeplex RV Detection kit for surveillance of respiratory viral outbreaks in Toronto, Ontario, Canada. Ann Clin Lab Sci. 2008;38:376-9.

11. WHO. Cumulative number of confirmed human cases of avian influenza A/(H5N1) Reported to WHO, 1 April 2011; 2011.

12. Peiris JS, de Jong MD, Guan Y. Avian influenza virus (H5N1): a threat to human health. Clin Microbiol Rev. 2007;20:243-67.

13. Ramadhany R, Setiawaty V, Wibowo H, Lokida D. Proportion of influenza cases in severe acute respiratory 
illness in Indonesia during 2008-2009. Med J Indones. 2010;19:264-7.

14. Waterer G, Wunderink R. Respiratory infections: a current and future threat. Respirology. 2009;14:651-5.

15. Dilantika C, Sedyaningsih ER, Kasper MR, Agtini M, Listiyaningsih E, Uyeki TM, et al. Influenza virus infection among pediatric patients reporting diarrhea and influenzalike illness. BMC Infect Dis. 2010;10:3.

16. Shek LP, Lee BW. Epidemiology and seasonality of respiratory tract virus infections in the tropics. Paediatr Respir Rev. 2003;4:105-11.

17. Abdel-Ghafar AN, Chotpitayasunondh T, Gao Z, Hayden FG, Nguyen DH, de Jong MD, et al. Update on avian influenza A (H5N1) virus infection in humans. N Engl J Med. 2008;358:261-73.

18. Kandun IN, Tresnaningsih E, Purba WH, Lee V, Samaan G, Harun S, et al. Factors associated with case fatality of human $\mathrm{H} 5 \mathrm{~N} 1$ virus infections in Indonesia: a case series. Lancet. 2008;372:744-9.

19. Kaji M, Watanabe A, Aizawa H. Differences in clinical features between influenza A H1N1, A H3N2, and B in adult patients. Respirology. 2003;8:231-3.

20. Simonsen L, Fukuda K, Schonberger LB, Cox NJ. The impact of influenza epidemics on hospitalizations. J Infect Dis. 2000;181:831-7.
21. Tang L, Wang L, Tan $\mathrm{X}, \mathrm{Xu}$ W. Adenovirus serotype 7 associated with a severe lower respiratory tract disease outbreak in infants in Shaanxi Province, China. Virol J. 2011;8:23

22. Hara K, Yahara K, Gotoh K, Nakazono Y, Kashiwagi T, Imamura $\mathrm{Y}$, et al. Clinical study concerning the relationship between community-acquired pneumonia and viral infection in northern Thailand. Intern Med. 2011;50:991-8.

23. Song JH, Oh WS, Kang CI, Chung DR, Peck KR, $\mathrm{Ko} \mathrm{KS}$, et al. Epidemiology and clinical outcomes of community-acquired pneumonia in adult patients in Asian countries: a prospective study by the Asian network for surveillance of resistant pathogens. Int J Antimicrob Agents. 2008;31:107-14.

24. Bezerra PG, Britto MC, Correia JB, Duarte Mdo C, Fonceca $\mathrm{AM}$, Rose $\mathrm{K}$, et al. Viral and atypical bacterial detection in acute respiratory infection in children under five years. PLoS One. 2011;6:e18928.

25. McCullers JA. Insights into the interaction between influenza virus and pneumococcus. Clin Microbiol Rev. 2006;19:571-82.

26. Murdoch DR, Chambers ST. Atypical pneumonia--time to breathe new life into a useful term? Lancet Infect Dis. 2009;9:512-9. 